\title{
Combining infliximab, anti-MAP and hyperbaric oxygen therapy for resistant fistulizing Crohn's disease
}

Background: Fistulizing Crohn's disease (CD) presents a therapeutic challenge as fistulae are notoriously difficult to heal. Mycobacterium avium ss paratuberculosis (MAP) treatment in $C D$ is gaining attention. Aim: We evaluated healing of $C D$ fistula(e) using a novel combination therapy. Study: Nine consecutive patients who failed to heal fistulae on conventional treatment including anti-TNF, were treated with at least three doses of infliximab, 18-30 courses of hyperbaric oxygen therapy and anti-MAP antibiotics comprising rifabutin, clarithromycin and clofazimine. Results: All patients achieved complete healing of fistulae by $6-28$ weeks and follow-up for mean 18 months. Conclusion: Combining infliximab, hyperbaric oxygen therapy and antiMAP, seems to enable healing of recalcitrant fistulae and although a small case series, all nine patients achieved complete healing.

Lay abstract: Nine consecutive patients with Crohn's disease and fistulae were treated with a special combination of infliximab, numerous hyperbaric oxygen sessions and combined antibiotics including rifabutin, clofazimine and clarithromycin as the base antibiotic combination - called anti-Mycobacterium avium ss paratuberculosis (MAP) therapy. At between 6 weeks and 6 months all fistulae healed - included rectovaginal - so that the skin was dry and there was no discharge and no need to wear a pad. Their Crohn's symptoms of diarrhea, urgency and bleeding also resolved. Continuation with anti-MAP therapy alone maintained healing although one patient who ceased the anti-MAP therapy had a relapse.

First draft submitted: 13 July 2015; Accepted for publication: 1 September 2015; Published online: 28 September 2015

Keywords: • Crohn's disease $\bullet$ fistula $\bullet$ hyperbaric oxygen therapy $\bullet$ infliximab

- Mycobacterium avium ss paratuberculosis

Due to the transmural nature of Crohn's disease (CD), approximately $20-40 \%$ of patients develop perianal fistulae [1,2], which is a distressing and potentially serious complication of the disease. Involvement may be severe and debilitating characterized by deep fistulae threatening the sphincter, numerous tracts, adjacent organ involvement and severe rectal disease [2], which restrict daily functioning, sexual activity [3] and overall quality of life [4,5]. Clinical features include painful induration, discharge, inconti- nence, general malaise and fever. Spontaneous healing of fistulae is rare, and they are frequently recalcitrant to treatment. Immunomodulatory agents (e.g., infliximab) represent a mainstay of fistulae treatment and achieve initial healing rates of around $60 \%[6,7]$. However their long-term effectiveness has been questioned in prospective, placebo-controlled trials $[7,8]$.

A possible causative link between Crohn's disease and Mycobacterium avium ss paratuberculosis (MAP) has been debated vigorously
Gaurav Agrawal', Thomas Borody ${ }^{*}, 1$, Robert Turner ${ }^{2}$, Sharyn Leis ${ }^{1} \&$ Jordana Campbell ${ }^{1}$

${ }^{1}$ Centre for Digestive Diseases, Level $1 / 229$ Great North Rd, Five Dock NSW 2046, Australia 2Prince of Wales Hospital, 1st Floor, Edmund Blacket Building, Randwick NSW 2031, Australia

*Author for correspondence: Tel.: +61 (02) 97134011 Fax: +61 (02) 97121675 drgagrawal@gmail.com 
and for a long time. It originated from early observed similarities between $\mathrm{CD}$ and Johne's Disease, the enteric MAP infection in cattle. In select institutions worldwide, antibiotic combination (anti-MAP) therapy has been offered as a treatment option for CD, often with striking results [9]. Preliminary findings have further demonstrated efficacy in achieving fistula healing in patients with severe $\mathrm{CD}$, with cure rates of $66.6 \%$ $(4 / 6)$ in a small case series, and partial healing in a further patient (1/6) [10]. Although a randomized trial by Selby et al. of anti-MAP [11] showed there was no efficacy in the long-term use of anti-Map in Crohn's, at 16 weeks it was reported by Selby as being highly effective $(\mathrm{p}=$ 0.02 ). However, his trial received published criticism in the Lancet as original calculations were flawed [12]. Indications for anti-MAP treatment generally include failure or poor response to other $\mathrm{CD}$ therapies and particularly in those facing colectomy. Contraindications include allergy to its various components and leucopenia.

Hyperbaric oxygen therapy (HBOT), the inhalation of $100 \%$ oxygen at a pressure of $>1$ ATM, is an established treatment for accelerating healing of chronic nonhealing wounds, for example, diabetic foot ulcers $[10,13]$. It presumably works by increasing tissue oxygen levels, relieving hypoxia and altering inflammatory pathways [14]. Given such possible mechanisms of action, its value as a potential treatment option for complex perianal $\mathrm{CD}$ has been identified [1]. HBOT has independently achieved complete healing rates of $45 \%$ and partial healing rates of $42.5 \%$ in a systematic meta-analysis [14], presumably through the targeting of anaerobic bacteria colonizing fistulae [7]. Patients are assessed by a specialist trained in HBOT to identify such comorbidities as inner ear pathology and asthma, among others.

Given the partial success individually of infliximab, HBOT and anti-MAP the potential of combining all three was explored in $\mathrm{CD}$ patients with treatmentrefractory fistulae. Some of these patients had reached the stage of being offered colectomy.

\section{Methods}

Nine consecutive patients with severely active CD and intractable fistulae were prospectively followed. All were nonresponsive to standard CD treatments, including corticosteroids, 5 amino salicylates (5ASA), thiopurines, methotrexate and biologics. All had documented $\mathrm{CD}$ and fistulae and after obtaining signed consent all were treated with a combination of:

- Infliximab $5 \mathrm{mg} / \mathrm{kg}$ (three to eight infusions; mean: 4.4 infusions);

- Continuous anti-MAP therapy (see Table 1 for details);
- HBOT concurrently $18-30$ daily sessions at 2.02.4 ATM (2-2.4 bar) for 90 min (mean: 21.8 sessions) in a monoplace or multiplace chamber.

Response was assessed by a change in clinical symptoms - particularly complete fistula healing with dry, nonoozing skin, colonoscopic findings of healed mucosa and pre- and post-treatment MRI improvement. Given an accuracy of $90 \%$, MRI is considered the preferred imaging modality for detecting and classifying fistulizing perianal disease, and was used in each case to confirm fistulae healing [15].

\section{Results}

Case 1

A 24-year-old male with long-standing CD presented with multiple rectum-to-rectum fistulae and inflammatory changes (Figure 1).

MRI confirmed the presence of multiple ( $>3)$ perirectal abscesses, the largest of these being $1 \mathrm{~cm}$ in diameter. The patient had failed previous numerous treatments. He underwent three infusions of infliximab and 30 sessions of HBOT, while being treated with combination anti-MAP (Table 1). At 3 months post-combination therapy, the patient was in asymptomatic clinical remission, with fistulae and abscesses undetectable on MRI (Figure 2). Healing persisted at 10 month colonoscopy and remains well at 2 years follow-up on maintenance anti-MAP therapy alone.

\section{Case 2}

A 32-year-old male presented with a 3-year history of $\mathrm{CD}$ and a high left-sided posterior, and right anterior fistulae, which required 'setons.' Symptoms included diarrhea, urgency and perianal discharge and tenderness. On colonoscopy, inflammation extended throughout the entire colon, with Crohn's ulcerations destroying areas of haustrations. The patient underwent three infliximab infusions, 21 HBOT sessions and anti-MAP therapy (Table 1). At 6 weeks review both fistulae healed and the skin was dry and the MRI was normal showing scarring only. Setons were removed during the latter stages of the HBOT therapy. Initially elevated inflammatory markers fell to within normal ranges. The patient continues well on anti-MAP therapy.

\section{Case 3}

A 32-year-old female presented with a 22-year history of $\mathrm{CD}$, complicated by a rectovaginal fistula (Figure 3). The patient's symptoms included severe dyspareunia and vaginal passage of gas especially during bowel evacuation. She also reported frequent loose motions, urgency, tenesmus, rectal bleeding and mucus. The patient had previously failed various treatments including a fistula 


\section{Table 1. Baseline patient characteristics.}

\begin{tabular}{|c|c|c|c|c|c|c|}
\hline $\begin{array}{l}\text { Age } \\
\text { (years) }\end{array}$ & Fistulae & Prior treatment & $\begin{array}{l}\text { Infliximab } \\
5 \mathrm{mg} / \mathrm{kg} \\
\text { doses }(\mathrm{n})\end{array}$ & Anti-MAP & $\begin{array}{l}\text { HBOT } \\
\text { sessions }\end{array}$ & Fistulae response \\
\hline 24 & $\begin{array}{l}\text { Multiple rectum-to- } \\
\text { rectum fistulae and } \\
\text { abscesses }\end{array}$ & $\begin{array}{l}\text { Azathioprine, EUAs and } \\
\text { seton drainage } \\
\text { Metronidazole } \\
\text { Infliximab } \\
\text { Mesalazine }\end{array}$ & 3 & $\begin{array}{l}\text { Rifabutin } \\
\text { Clofazimine } \\
\text { Clarithromycin } \\
\text { Ethambutol } \\
\text { Ciprofloxacin } \\
\text { Metronidazole }\end{array}$ & 30 & $\begin{array}{l}\text { Complete healing. } \\
\text { Healed mucosa persisted } \\
\text { at } 20 \text {-month review }\end{array}$ \\
\hline 32 & $\begin{array}{l}\text { High left-sided } \\
\text { posterior and right } \\
\text { superficial anterior } \\
\text { perianal/rectal fistula }\end{array}$ & $\begin{array}{l}\text { Seton insertion/EUA } \\
\text { Azathiopurine and } \\
\text { infliximab }\end{array}$ & 3 & $\begin{array}{l}\text { Rifabutin } \\
\text { Clofazimine } \\
\text { Clarithromycin } \\
\text { Ethambutol } \\
\text { Ciprofloxacin } \\
\text { Metronidazole }\end{array}$ & 30 & $\begin{array}{l}\text { Complete healing. } \\
\text { Healed mucosa persisted } \\
\text { at } 10 \text {-month review }\end{array}$ \\
\hline 31 & $\begin{array}{l}\text { Right intersphincteric } \\
\text { fistula and a posterior } \\
\text { anal fissure }\end{array}$ & $\begin{array}{l}\text { Azathioprine infliximab } \\
\text { previous bowel } \\
\text { resection }\end{array}$ & 4 & $\begin{array}{l}\text { Rifabutin } \\
\text { Clofazimine } \\
\text { Clarithromycin } \\
\text { Ethambutol } \\
\text { Metronidazole }\end{array}$ & 18 & $\begin{array}{l}\text { Complete healing with } \\
\text { healed mucosa. Posterior } \\
\text { fissure remained, } \\
\text { minimal in size at } \\
6 \text { weeks }\end{array}$ \\
\hline 20 & Three perianal fistulae & $\begin{array}{l}\text { Mesalazine prednisone } \\
\text { infliximab anti-MAP tx } \\
\text { alone }\end{array}$ & 3 & $\begin{array}{l}\text { Rifabutin } \\
\text { Clarithromycin } \\
\text { Clofazimine } \\
\text { Ethambutol } \\
\text { Ciprofloxacin } \\
\text { Azathioprine }\end{array}$ & 21 & $\begin{array}{l}\text { Complete healing. } \\
\text { Healed mucosa, } \\
\text { remained healed at } \\
\text { 8-year follow-up, } \\
\text { without setons }\end{array}$ \\
\hline 27 & Four open fistula tracts & $\begin{array}{l}\text { Multiple setons in situ } \\
\text { Failed EUA and } \\
\text { fistulotomy } \\
\text { Infliximab steroids }\end{array}$ & 6 & $\begin{array}{l}\text { Rifabutin } \\
\text { Clofazimine } \\
\text { Clarithromycin } \\
\text { Ethambutol } \\
\text { Metronidazole }\end{array}$ & 20 & $\begin{array}{l}\text { Partial closure of } \\
\text { fistulae tract on MRI. } \\
\text { No discharge or pain. } \\
\text { Perianal abscess } \\
\text { persisted then resolved }\end{array}$ \\
\hline 40 & Two perianal fistulae & $\begin{array}{l}\text { EUA and seton drainage } \\
\text { and metronidazole } \\
\text { Infliximab }\end{array}$ & 5 & $\begin{array}{l}\text { Rifabutin } \\
\text { Clofazimine } \\
\text { Clarithromycin } \\
\text { Ethambutol } \\
\text { Metronidazole }\end{array}$ & 20 & Healed fistulae \\
\hline 52 & $\begin{array}{l}\text { Complex } \\
\text { intersphincteric fistulae. } \\
\text { Lower rectal wall } \\
\text { abscess }\end{array}$ & $\begin{array}{l}\text { Multiple EUA setons } \\
\text { Metronidazole } \\
\text { Infliximab }\end{array}$ & 8 & $\begin{array}{l}\text { Rifabutin } \\
\text { Clofazimine } \\
\text { Clarithromycin } \\
\text { Ethambutol } \\
\text { Metronidazole }\end{array}$ & 21 & $\begin{array}{l}\text { Complete healing of } \\
\text { fistulae }\end{array}$ \\
\hline
\end{tabular}




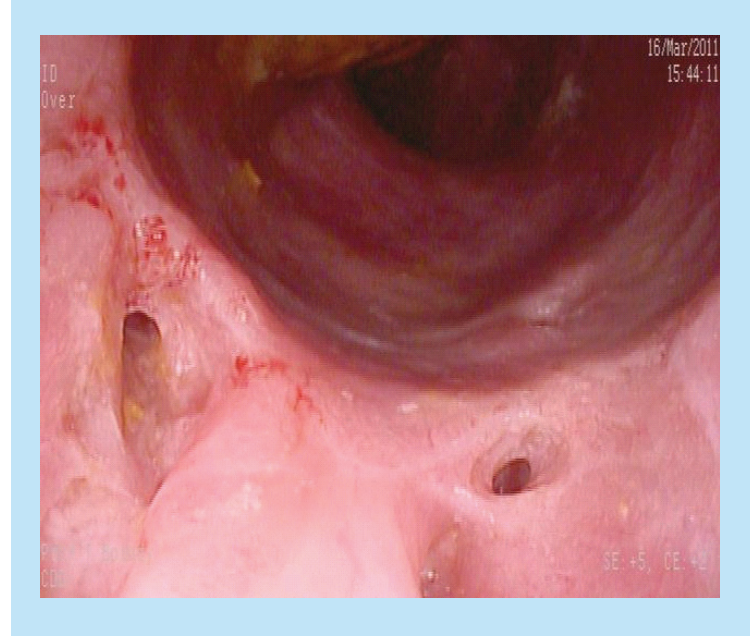

Figure 1. Pretreatment - multiple fistulae and inflammatory changes.

treatment with infliximab alone. On colonoscopy, active, ulcerating $\mathrm{CD}$ was confirmed, with a visible fistula opening (Figure 3). Combination therapy consisted of four infliximab infusions, 21 HBOT sessions and anti-MAP therapy (Table 1). After 3 months, the patient reported increased energy, resolution of bowel symptoms and the return of previously absent menses. Complete rectal and vaginal fistula healing was observed on colonoscopy (Figure 4). Subsequent MRI showed disappearance of the original abnormalities in the anorectal area with no gascontaining locus and absence of the rectovaginal fistula. However, feeling so well at follow-up she decided to discontinue anti-MAP therapy and her symptoms recurred and fistula reopened.

\section{Case 4}

A 31-year-old male with a 10-year history of CD presented with lower abdominal and rectal pain, bloating, flatulence, fecal urgency and soiling. On colonoscopy, the patient had a posterior anal fissure and an inter-

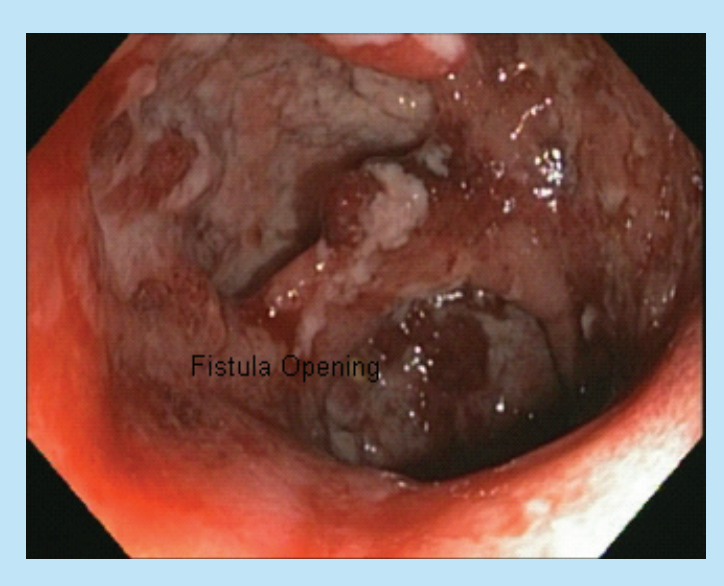

Figure 3. Pretreatment - rectovaginal fistula.

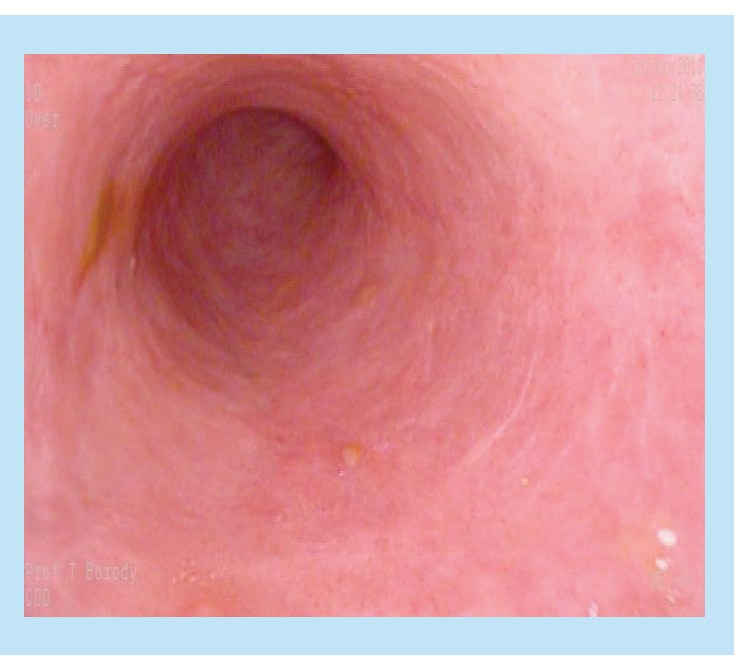

Figure 2. Post-treatment - endoscopic healing of previous fistulae.

sphincteric fistula (Figure 5). He had previously failed infliximab and later surgery and was now initiated on four infliximab infusions coupled with 18 HBOT sessions and anti-MAP therapy (Table 1). After 6 weeks of this combination therapy the patient reported resolution of clinical symptoms and was passing one to two formed motions per day. Fistula healing was confirmed by inspection and via colonoscopy, with what appeared to be a healing remnant fissure (Figure 6).

\section{Case 5}

A 40-year-old female presented with CD symptoms of rectal bleeding, urgency, fatigue, anemia and three perianal fistulae. Her fistulae were previously treated with long-term 'setons' accompanied by various treatments including infliximab without complete healing. The patient was initiated on anti-MAP therapy before the addition of 21 HBOT sessions and three doses of infliximab. She experienced dramatic improvement permitting removal of 'setons' and complete healing of all fistulae. Progressive CD remission occurred within 4-6

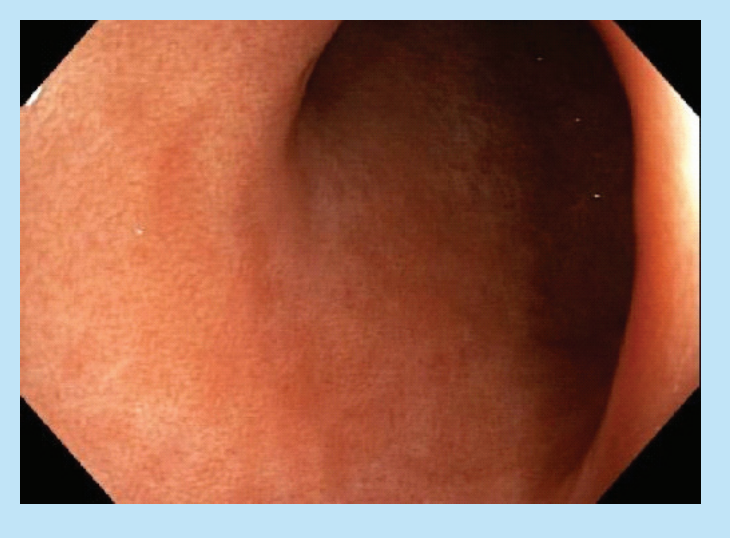

Figure 4. Post-treatment - endoscopically healed. 


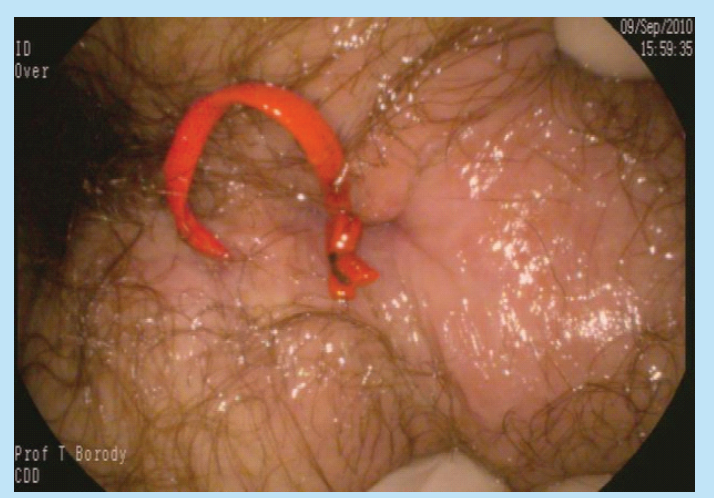

Figure 5. Pretreatment - perianal fistula.

weeks. A marked reduction in stool frequency was also observed to one formed stool per day from her baseline of $>10$ stools per day. There was no associated urgency, pain or tenesmus. She has remained asymptomatic without recurrence of fistulae over the last 7 years on a maintenance dose of anti-MAP therapy alone.

\section{Case 6}

A 38-year-old female presented with markedly active CD (CDAI of 416) and an unresolving deep rectolabial fistula that had been present for over a year, despite mesalazine, prednisolone and azathioprine therapy, later infliximab. Colonoscopy revealed extensive ulceration, contact bleeding, pus and inflammation in the left colon. Combination therapy included 21 sessions of HBOT, which led to complete fistula healing, which was confirmed via MRI. The patient also experienced improvement in CD symptoms, reporting two to three soft, formed stools daily, with an absence of blood, fecal urgency and tenesmus. Her CDAI score reduced to 15 .

\section{Case 7}

A 27-year-old male presented with four fistula tracts requiring setons in situ due to numerous intractable fistulae and abscesses requiring extensive (nine) surgical intervention intravenous antibiotics, anti-inflammatory

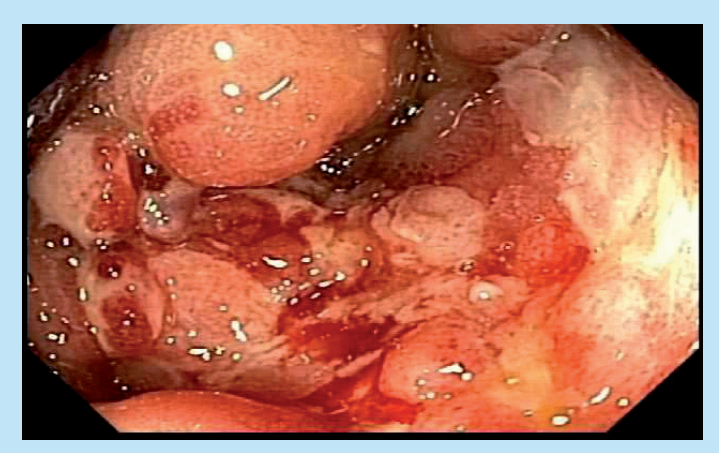

Figure 7. Pretreatment - rectal inflammation.

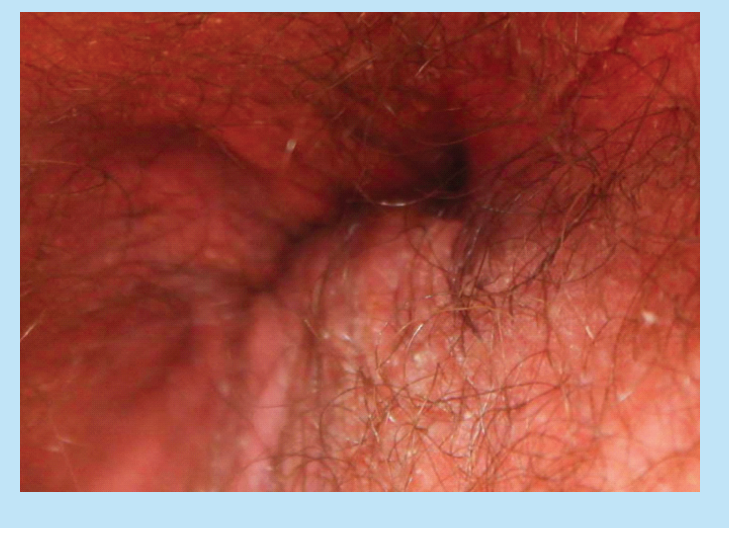

Figure 6. Post-treatment - healed fistula with remnant fissure.

drugs and infliximab (Figures $7 \& 8$ ). The patient had an initial CDAI of 501, with weight loss of $29 \mathrm{~kg}$, and severe anal and pelvic pain. He was commenced on antiMAP therapy combined with infliximab, and experienced symptomatic improvement. The fistula tracts healed slowly until his HBOT appointment became available for 20 sessions, during which his fistulae progressively healed. At 1-year review, his CDAI score was 76 and repeat examination and colonoscopy revealed completely healed mucosa and fistulae (Figures $9 \& 10$ ).

\section{Case 8}

A 40-year-old male with a 16-year history of CD presented with active CD with a CDAI score of 365 , and a persistent anorectal fistula. An MRI showed two small perianal fistula tracts. After three doses of infliximab, 21 courses of HBOT and anti-MAP oral antibiotics he improved rapidly and at 6-month follow-up, the fistulae were healed accompanied by complete macroscopic healing of the bowel at colonoscopy.

\section{Case 9}

A 52-year-old male presented with complex perianal Crohn's Disease, which involved a fistula in the

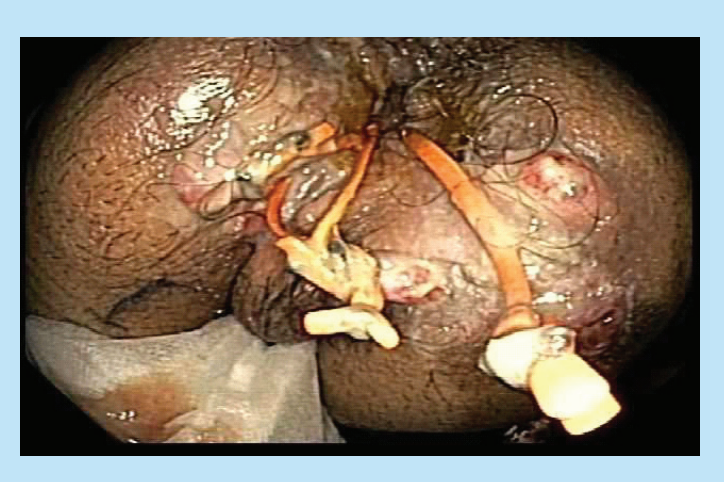

Figure 8. Pretreatment - multiple fistulae. 


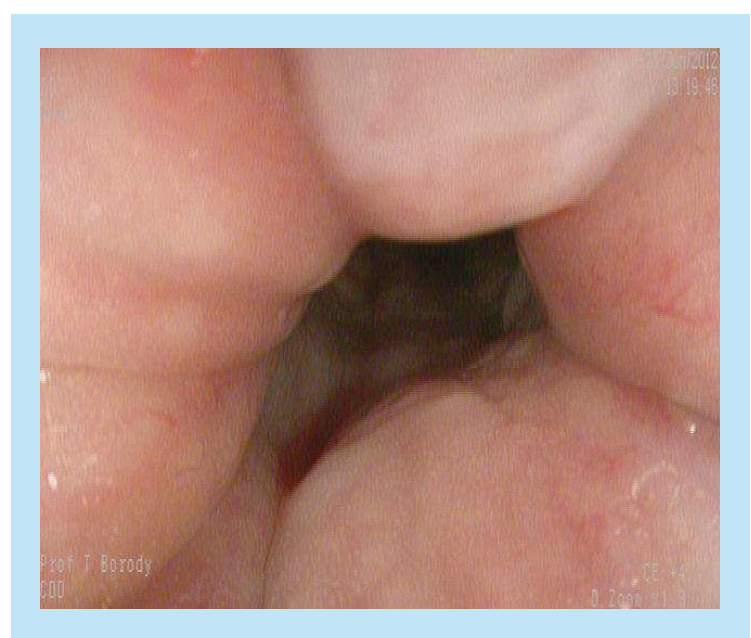

Figure 9. Post-treatment - healed mucosa.

intersphincteric space with a small collection in the lower-third of the rectal wall. The patient experienced chronic perianal sepsis as a result, which was resistant to treatment and drainage (Figures $11 \& 12$ ). A partial proctocolectomy was performed. Following one years' treatment with anti-MAP therapy, eight courses of infliximab and 21 sessions of HBOT. The patient underwent an ileorectal reconnection, with complete healing of $\mathrm{CD}$ and resolution of fistula, and remains on anti-MAP maintenance therapy alone (Figures 13 \& 14).

\section{Discussion}

In this difficult-to-treat population of patients with severe, active $\mathrm{CD}$, who had previously failed conventional therapies (including 5ASA, steroids, infliximab, thiopurines and anti-MAP), combination therapy with infliximab, HBOT and anti-MAP therapy achieved $100 \%$ fistulae healing rates in this small cohort. This healing persisted for an average of 18 months with continuation of anti-MAP but on stopping anti-MAP fistulae returned in one patient. This appears to be

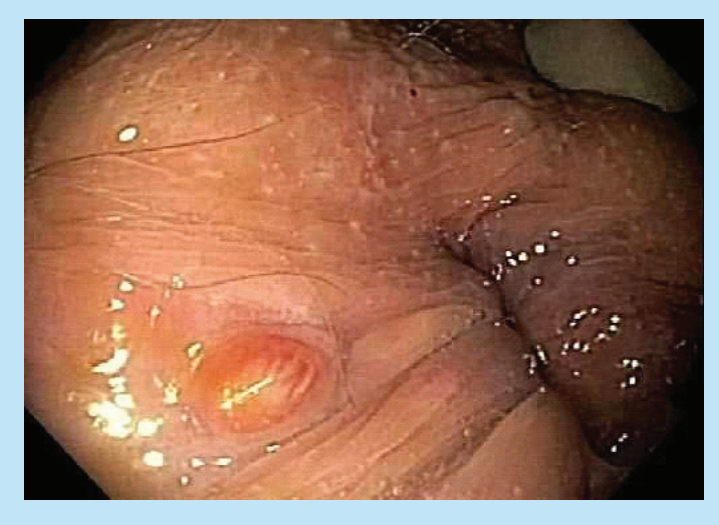

Figure 11. Pretreatment - fistula opening.

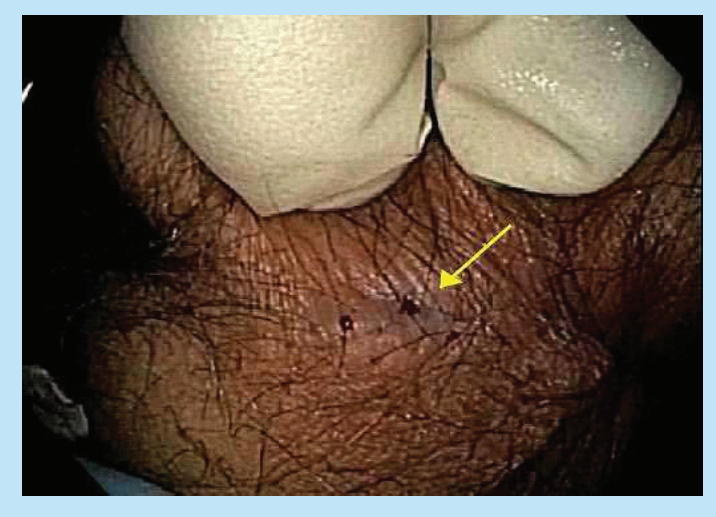

Figure 10. Post-treatment - healed fistula opening.

higher than comparable data for each of the three therapies individually, and indeed any available treatments $[10,16-17]$. Fistulizing CD frequently presents a therapeutic challenge and significantly impacts on patients' quality of life. Certain medications that are useful for the treatment of active Crohn's disease may be counterintuitive in the treatment of CD fistulae (e.g., corticosteroids), and can in fact be detrimental [18]. Biologics such as infliximab have improved fistulae treatment - otherwise most cases are intractable and require 'seton' placement to prevent abscess formation. While the initial response to infliximab can be dramatic, the median duration of fistula closure is approximately 3 months [19]. In the initial infliximab Phase II and subsequent Phase III trials, 56-68\% of fistulae initially healed in 296 patients [1,2]. In the ACCENT 2 trial, there was a $60 \%$ response rate of fistulae after 14 weeks. However, on an intention-to-treat basis, at one year only approximately $20 \%$ of fistulae healed in patients treated with infliximab $[8]$. This leaves the vast majority of patients experiencing continued fistulizing activity, with a subgroup of these patients progressing to proctectomy and a permanent stoma $[16,18]$. In addition, not all fistulae respond to infliximab. Rectovaginal fistulae

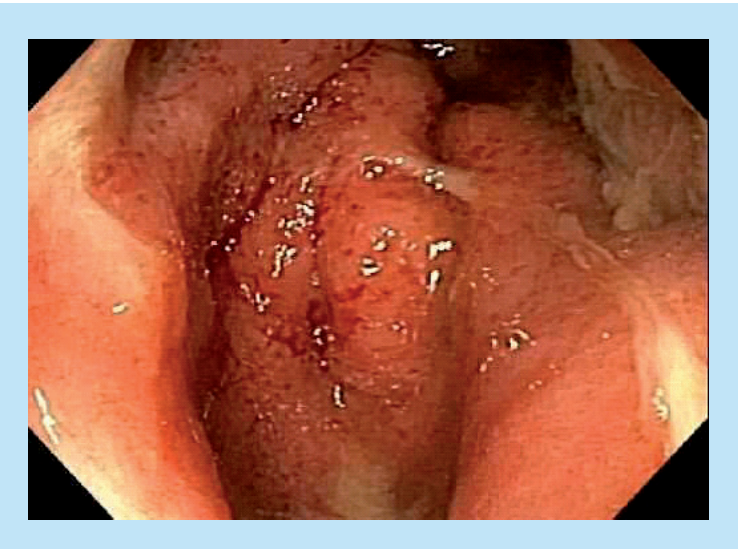

Figure 12. Pretreatment - rectal inflammation opening. 
have a poor response to infliximab alone, achieving initial healing rates of $14-30 \%$ compared with $46-78 \%$ for perianal fistulae [19].

In our small study, using the combination of infliximab, HBOT and anti-MAP therapy achieved high healing rates of perianal fistulae, including rectovaginal fistulae. Patients had severe CD and were refractory to a number of therapies, including infliximab and anti-MAP therapy alone. Not only did they experience resolution of fistulae, but all nine patients experienced an improvement in CD symptoms. These patients had failed infliximab with or without thiopurines in the past. Given infliximab also has anti-MAP activity [20] we decided to use a short course of infliximab (three to eight infusions) to accelerate healing and continue with $\mathrm{HBOT}$ and the antibiotics, as we felt longer term immune suppression may be counterproductive to antibiotic effectiveness. The synergistic effect experienced in these patients may be explained by the differing and potentially complementary actions of these therapies. Treatment of CD using anti-MAP antibiotics with known intracellular activity against MAP, such as rifabutin and clarithromycin, have been shown to induce prolonged remission of $\mathrm{CD}$, and at times deep, longitudinal scarring associated with more profound healing [21]. Similarly, Borody et al. have shown fistula healing in three out of five patients treated with anti-MAP therapy [10]. Adverse effects of anti-MAP therapy include redness of body fluids, red tan effect of the skin, arthralgia, transient leucopenia and elevated liver function tests, as the most common and rarely uveitis. An encouraging aspect is the relative low incidence of side effects from these drugs. Typically red discoloration of secretions and skin occur in all patients, while transaminase elevation, leucopenia, uveitis and fevers are largely avoided by a step-up dosing approach.

Due to their location, perianal fistulae are frequently prone to coexisting infection as a result of stool bacterial contamination. Fistulae are proposed to persist due to ongoing ischemia and persistent colonization with anaerobic microorganisms [22]. HBOT is a novel treatment targeting anaerobic bacteria colonizing $\mathrm{CD}$ fistulae. Due to the mechanism of action of HBOT, its potential value in fistulae treatment has previously been recognized [23]. Higher atmospheric oxygen environment during HBOT creates unsuitable conditions for anaerobe survival. HBOT also inhibits active inflammation, in part by suppressing TNF- $\alpha$, IL-1 and IL- 6 and enhancing host antibacterial responses [16,24]. Furthermore, HBOT decreases neopterin, myeloperoxidase activity and oxidative stress markers, whilst stimulating angiogenesis [25]. Sporadic case reports of Crohn's perianal disease achieving complete healing on HBOT and

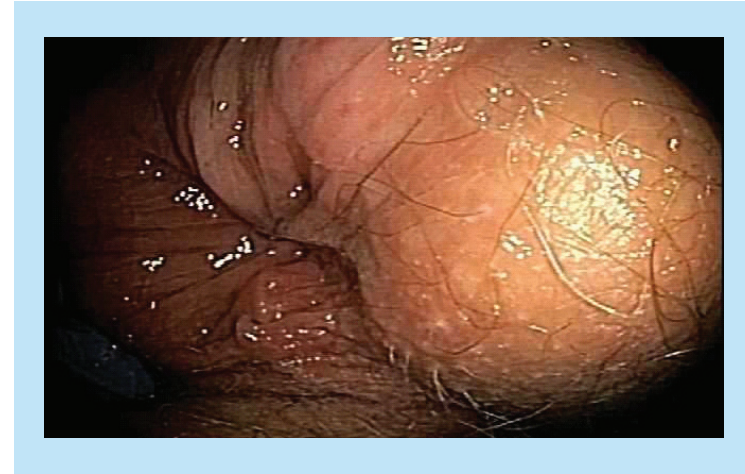

Figure 13. Post-treatment - healed opening.

non-anti-MAP antibiotics exist [26]. Two uncontrolled prospective studies have been conducted involving a subset of refractory CD patients. In one, ten patients with refractory perianal Crohn's disease underwent $90 \mathrm{~min}$ daily sessions for 20 days at a pressure of 2.5 ATM. After two courses, $50 \%$ of patients experienced complete healing, with a three [rd] course increasing this rate to $70 \%$. At 18 months follow-up there was no evidence of recurrence [27]. Similar results were shown in another small trial [28]. Brady et al. reported a patient with an 8 -year refractory CD fistula that healed with one session of HBOT [22]. Minimal adverse effects also exist with HBOT [29].

It is therefore likely that a combination of these diverse mechanisms enabled the profound healing of fistulae seen in these patients, and allowed the subsequent effective maintenance of $\mathrm{CD}$ with anti-MAP therapy alone. The effect of the combination therapy generally became evident soon after commencement of the therapy, and such early response could be used to indicate surgery can be avoided. One of the major limitations of this study lies in the use of all three treatments (IFX, HBOT and anti-MAP) concurrently. Hence, it is difficult or even impossible to assess which of these treatments is or are particularly responsible for results of such quality. It is possible that only two of the three treatments used together would provide similar results. Also, this is not a prospective study but all-comer consecutive patients are

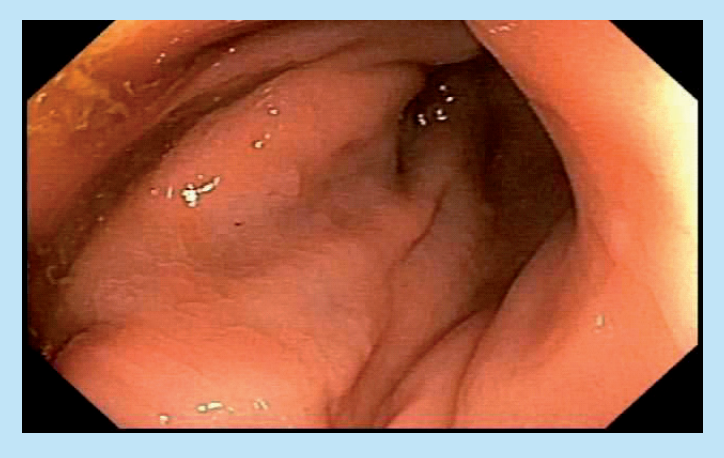

Figure 14. Post-treatment - healed rectal mucosa. 
reported, variations existed among patients, for example, severity of the Crohn's disease, duration of each treatment, number of HBOT sessions and antibiotic regimens (Table 1). This heterogeneity and small patient numbers limit the conclusions of this study. The primary goal of fistula healing was achieved in all patients. Differences in pretreatment severity of the disease to a large extent accounted for the differing treatment durations.

\section{Conclusion}

Our results demonstrate that combining infliximab with anti-MAP therapy and HBOT can achieve a high healing rate of perianal fistulae in Crohn's disease, including rectovaginal fistulae. The use of such combination treatment is a viable option for the treatment of persistent and recurrent fistulae. Future studies using larger sample sizes will enable analysis of fistula characteristics which could predict long-term healing with this combination of therapies.

\section{Author contributions}

All authors were personally involved in treating the patients and collecting data. G Agrawal, T Borody and J Campbell con- ceived the report and wrote sections each. S Leis and R Turner contributed clinical and hyperbaric data and modified and edited the piece.

Financial \& competing interests disclosure

G Agrawal and T Borody have filed patents in the field of antiMAP therapy. No sponsors funded this research. The authors have no other relevant affiliations or financial involvement with any organization or entity with a financial interest in or financial conflict with the subject matter or materials discussed in the manuscript apart from those disclosed.

No writing assistance was utilized in the production of this manuscript.

\section{Informed consent disclosure}

The authors state that they have obtained verbal and written informed consent from the patient/patients for the inclusion of their medical and treatment history within this case series.

\section{Open access}

This work is licensed under the Creative Commons Attribution 4.0 License. To view a copy of this license, visit http://creativecommons.org/licenses/by/4.0/

\section{Executive summary}

- Crohn's disease can be complicated by fistulae development between the rectum and the external skin of the anus, and from the rectum to the vagina in more than $20-40 \%$ of patients. This is a distressing and chronic complication with poor response to current therapies.

- The arrival of the immunomodulator, infliximab (Remicade) has improved healing with initial rates being $60 \%$ but in the long-term healing falls to below $40 \%$ in spite of administering Remicade.

- Oxygen therapy in a hyperbaric chamber (hyperbaric oxygen therapy) and special combinations of antibiotics targeting Mycobacterium avium ss paratuberculosis (MAP) have also been shown to heal fistulae but in no more than $30-50 \%$ of patients. Combining these partially effective treatments has not been reported.

- This report describes the use in nine consecutive patients of a combination of infliximab, hyperbaric oxygen and anti-MAP therapy used together, to see if greater healing of fistulae is achieved and if maintenance of healing is possible with the anti-MAP component.

- Although this study is quite small and future results may see some failures, all first nine patients treated with this method healed their fistulae completely without any discharge and without the need to wearing pads to absorb leakage. This appears to be a combination that is worth working with, perhaps optimizing the use of infliximab and hyperbaric oxygen therapy to further optimize healing rates and improve maintenance of healing with long-term antibiotic usage.

\section{References}

Papers of special note have been highlighted as:

- of interest; $\bullet$ of considerable interest

1 Taxonera C, Schwartz DA, Garcia-Olmo D. Emerging treatments for complex perianal fistula in Crohn's disease. World J. Gastroenterol. 15(34), 4263-4272 (2009).

2 Koltun W. A paradigm for the management of complex perineal Crohn's disease in the anti-TNF era. Semin. Colon Rectal. Surg. 17(2), 61 (2006).

3 Feller ER, Ribaudo S, Jackson ND. Gynecologic aspects of Crohn's disease. Am. Fam. Physician 64(10), 1725-1728 (2001).
$4 \quad \mathrm{Ng}$ SC, Plamondon S, Gupta A, Burling D, Kamm MA. Prospective assessment of the effect on quality of life of anti-tumour necrosis factor therapy for perineal Crohn's fistulas. Aliment. Pharmacol. Ther. 30(7), 757-766 (2009).

5 Mahadev S, Young JM, Selby W, Solomon MJ. Quality of life in perianal Crohn's disease: what do patients consider important? Dis. Colon Rectum. 54(5), 579-585 (2011).

6 Present DH, Rutgeerts P, Targan $S$ et al. Infliximab for the treatment of fistulas in patients with Crohn's disease. N. Engl. J. Med. 340(18), 1398-1405 (1999). 
7 Sands BE, Anderson FH, Bernstein CN et al. Infliximab maintenance therapy for fistulizing Crohn's disease. $N$. Engl. J. Med. 350(9), 876-885 (2004).

8 Hart AL, Plamondon S, Kamm MA. Topical tacrolimus in the treatment of perianal Crohn's disease: exploratory randomized controlled trial. Inflamm. Bowel Dis. 13(3), 245-253 (2007).

9 Chamberlin W, Borody TJ, Campbell J. Primary treatment of Crohn's disease: combined antibiotics taking center stage. Expert Rev. Clin. Immunol. 7(6), 751-760 (2011).

10 Borody TJ, Bilkey S, Wettstein A, Leis S, Tye S. AntiMycobacterium avium SS paratuberculosis (MAP) therapy and fistula closure in patients with severe Crohn's Disease. Am. J. Gastroenterol. 101, S440 (2006).

11 Selby W, Pavli P, Crotty B et al. Two year combination therapy with clarithromycin, rifabutin, and clofazimine for Crohn's disease. Gastroenterology 132(7), 2313-2319 (2007).

12 Behr MA, Hanley J. Antimycobacterial therapy for Crohn's disease: a reanalysis. Lancet Infect. Dis. 8(6), 344 (2008).

- Recalculated Selby results indicating the anti-Mycobacterium avium ss paratuberculosis therapy is effective in the treatment of Crohn's disease.

13 Kranke P, Bennett MH, Martyn-St James M, Schnabel A, Debus SE. Hyperbaric oxygen therapy for chronic wounds. Cochrane Database Syst. Rev. 4, CD004123 (2012).

14 Dulai PS, Gleeson MW, Taylor D, Holubar SD, Buckey JC, Siegel CA. Systematic review: the safety and efficacy of hyperbaric oxygen therapy for inflammatory bowel disease. Aliment. Pharmacol. Ther. 39(11), 1266-1275 (2014).

15 Schwartz DA, Wiersema MJ, Dudiak KM et al. A comparison of endoscopic ultrasound, magnetic resonance imaging, and exam under anesthesia for evaluation of Crohn's perianal fistulas. Gastroenterology 121(5), 1064-1072 (2001).

16 Noyer CM, Brandt LJ. Hyperbaric oxygen therapy for perineal Crohn's disease. Am. J. Gastroenterol. 94(2), 318-321 (1999).

17 Parsi MA, Lashner BA, Achkar JP, Connor JT, Brzezinski A. Type of fistula determines response to infliximab in patients with fistulous Crohn's disease. Am. J. Gastroenterol. 99(3), 445-449 (2004).

18 Lichtenstein GR. Treatment of fistulizing Crohn's disease. Gastroenterology 119(4), 1132-1147 (2000).

19 Lewis RT, Maron DJ. Efficacy and complications of surgery for Crohn's disease. Gastroenterol. Hepatol. 6(9), 587-596 (2010).

20 Bach H, Rosenfeld G, Bressler B. Treatment of Crohn's disease patients with infliximab is detrimental for the survival of Mycobacterium avium ssp. paratuberculosis within macrophages and shows a remarkable decrease in the immunogenicity of mycobacterial proteins. J. Crohns Colitis 6(5), 628-629 (2012).

- Letter indicating that treatment with infliximab inhibits the growth of Mycobacterium avium paratuberculosis. It would make sense then to use infliximab together with other therapies for Mycobacterium avium ss paratuberculosis.

21 Borody TJ, Bilkey S, Wettstein AR, Leis S, Pang G, Tye S. Anti-mycobacterial therapy in Crohn's disease heals mucosa with longitudinal scars. Dig. Liver. Dis. 39(5), 438-444 (2007).

22 Brady CE 3rd, Cooley BJ, Davis JC. Healing of severe perineal and cutaneous Crohn's disease with hyperbaric oxygen. Gastroenterology 97(3), 756-760 (1989).

23 Bedioui H, Makni A, Magherbi H, Ben Safta Z. Hyperbaric oxygen in the treatment of perineal Crohn's disease era of infliximab: a renewal interest? La Tunisie medicale 90(6), 4 (2012).

24 Weisz G, Lavy A, Adir Y et al. Modification of in vivo and in vitro TNF-alpha, IL-1, and IL-6 secretion by circulating monocytes during hyperbaric oxygen treatment in patients with perianal Crohn's disease. J. Clin. Immunol. 17(2), 154-159 (1997).

25 Lin KC, Niu KC, Tsai KJ et al. Attenuating inflammation but stimulating both angiogenesis and neurogenesis using hyperbaric oxygen in rats with traumatic brain injury. J. Trauma Acute Care Surg. 72(3), 650-659 (2012).

26 Sipahi AM, Damiao AO, de Sousa MM et al. Hyperbaric oxygen: a new alternative in the treatment of perianal Crohn's disease. Rev. Hosp. Clin. Fac. Med. Sao Paulo 51(5), 189-190 (1996).

27 Lavy A, Weisz G, Adir Y, Ramon Y, Melamed Y, Eidelman S. Hyperbaric oxygen for perianal Crohn's disease. J. Clin. Gastroenterol. 19(3), 202-205 (1994).

28 Colombel JF, Mathieu D, Bouault JM et al. Hyperbaric oxygenation in severe perineal Crohn's disease. Dis. Colon Rectum 38(6), 609-614 (1995).

- In this paper, ten patients were well studied using hyperbaric oxygen therapy as a contributor to healing. Six out of eight showed either partial or complete healing where other therapies failed.

29 Rossignol DA. Hyperbaric oxygen treatment for inflammatory bowel disease: a systematic review and analysis Crohn's disease. Med. Gas Res. 2(1), 6 (2012).

-. In this paper, ten patients were well studied using hyperbaric oxygen therapy as a contributor to healing. Six out of eight showed either partial or complete healing where other therapies failed. 